\title{
The genus Allodia (Diptera: Mycetophilidae) in Miocene Ethiopian amber
}

\author{
Valentine Bouju $^{1}$, Simon Rosse-Guillevic ${ }^{1}$, Marion Griffon ${ }^{1}$, Błażej Bojarski ${ }^{2}$, Jacek Szwedo ${ }^{2}$, and Vincent Perrichot ${ }^{1}$ \\ ${ }^{1}$ Géosciences Rennes, CNRS, UMR 6118, Univ Rennes, 35000 Rennes, France \\ ${ }^{2}$ Laboratory of Evolutionary Entomology and Museum of Amber Inclusions, Department of Invertebrate Zoology and \\ Parasitology, Faculty of Biology, University of Gdańsk, 59 Wita Stwosza St., 80-309 Gdańsk, Poland
}

Correspondence: Vincent Perrichot (vincent.perrichot@univ-rennes1.fr)

Received: 14 May 2021 - Revised: 6 September 2021 - Accepted: 23 September 2021 - Published: 18 October 2021

\begin{abstract}
A new, extinct species of Allodia Winnertz is described from early Miocene amber of Ethiopia. Allodia paleoafricana sp. nov. is mostly characterized by the scutum with strong anteromarginal, dorsocentral, and lateral setae and the wing with the stem of the M-fork slightly shorter than the vein $\mathrm{r}-\mathrm{m}$ and the base of the M4-CuA fork aligned with the base of $\mathrm{r}-\mathrm{m}$. The assignment to any of the two subgenera $\mathrm{Al}$ lodia stricto sensu or Brachycampta Winnertz remains equivocal as the fossil intermingles traits found in both taxa. Allodia is known mostly from the Palearctic region, while only a few species have been described from Africa. In this regard, the new fossil species from Ethiopia brings significant new information regarding the Afrotropical distribution and natural history of the genus.
\end{abstract}

\section{Introduction}

Mycetophilidae, also known as true fungus gnats, is a diversified family of Sciaroidea (Diptera), with approximately 4500 species described to date (Magnussen, 2020). The family is composed of six subfamilies including the Mycetophilinae considered herein, which itself is divided into two tribes: Mycetophilini and Exechiini (Søli, 2017; Burdíková et al., 2019). The second is less diversified but still contains about 700 species in 20 genera, among which the most speciose taxa are Exechia Winnertz, 1863; Exechiopsis Tuomikoski, 1966; Brevicornu Marshall, 1896; and Allodia Winnertz, 1863 (Rindal et al., 2007; Burdíková et al., 2019; Magnussen, 2020). Exechiini is distributed worldwide, with its greatest diversity in the Holarctic region (Matile, 1989; Kjærandsen et al., 2007; Rindal et al., 2007; Oliveira and Amorim, 2014).
Exechiini is estimated to have originated during the Paleogene, 23-66 million years (Myr) ago, with a subsequent rapid diversification during the Neogene (2.58-23 Ma) (Burdíková et al., 2019; Camier and Nel, 2020). Fossil Exechiini is mostly found in 34-38-million-year-old Eocene Baltic amber, from which forty species have been described in seven genera, including Allodia (Meunier, 1904, 1916, 1917, 1923; Burdíková et al., 2019). The discovery of a 16-23million-year-old species of Allodia, described herein from early Miocene Ethiopian amber, is thus significant for evolutionary studies of the genus, and more generally those of the Afrotropical mycetophilid diversity which is poorly studied and surely underestimated (Kurina, 2012; Magnussen et al., 2018).

\section{Material and methods}

\subsection{Amber deposit and age}

The specimen studied herein is preserved in a piece of amber originating from Ethiopia. It was purchased from a gem trader in Addis Ababa and later accessed by paleoentomologists at the University of Gdańsk. As is often the case with Ethiopian amber gathered by traders, the precise locality remains unknown as the material is collected from at least four localities and can be mixed up in bags of raw pieces available for sale. However, all localities are situated in the North Shewa Zone (NSZ) and South Wollo Zone (SWZ) of the Amhara Region, on the slopes of the major rivers and their tributaries (Schmidt et al., 2010; Coty et al., 2016; Bouju and Perrichot, 2020; Bouju et al., 2021, fig. 2 for a map with localities): a first outcrop was reported by Schmidt et al. (2010) 
from the northwestern part of the NSZ, in a gorge of the river Wenchit, near the town of Alem Ketema; Coty et al. (2016) obtained some amber from another outcrop located near the hamlet of Jema, along the river Jamma; a third outcrop, further east, was accessed by two of us (Vincent Perrichot and Valentine Bouju) in 2019, in a locality named Woll down the gorge of an affluent of the river Jamma; and a fourth one, the westernmost, was reported to us by a trader near the town of Fiche, again in an affluent of the Jamma river (Binyam Teferi, personal communication, 2019). The material accessed by the University of Gdańsk, although without a precise locality, comes from southeast of the SWZ, near the town of Weldiya (Marcin Buzalski, personal communication, 2013). Data from local collectors and from analyses of the amber-bearing matrix indicate that in all these localities, the amber apparently originates from the same geological layer and can be considered coeval.

The areas of the NSZ and SWZ mentioned above are mostly covered by Miocene to Quaternary layers, the stream gorges cutting through Cretaceous to Miocene deposits (Belay et al., 2009). The lower layer, more or less covered by the streams, corresponds to Upper Cretaceous sandstones from the geological formation named Debre Libanos Sandstone or Upper Sandstone (Belay et al., 2009). Ethiopian amber was first suggested to originate from this Cretaceous layer, mostly because of erroneous palynomorph determinations (Schmidt et al., 2010; Perrichot et al., 2016, 2018). However, further studies of the palynomorphs from the original and additional material enabled a new estimation of the amber age, now considered to be early Miocene (16-23 Myr old; Perrichot et al., 2018; Bouju and Perrichot, 2020). This new dating is congruent with the field observations made by two of us (Vincent Perrichot and Valentine Bouju) in the Woll locality, where the amber layer is found down the slopes between under- and overlying basaltic layers deposited during preOligocene to Miocene volcanic episodes (Hofmann et al., 1997; Coulié et al., 2003; Kieffer et al., 2004; Belay et al., 2009). Unfortunately, no radiometric age could be obtained from these basaltic layers observed in Woll.

Chemical analyses of the resin revealed a Class 1c amber typical of angiosperms in the family Fabaceae. Some leaves and flower remains related to Hymenaea were also found in inclusions, suggesting this genus as the resin producer (Bouju and Perrichot, 2020).

\subsection{Preparation and study of the fossil}

The specimen was found preserved in a piece of yelloworange amber with 10 other inclusions (Diptera, Hymenoptera, Hemiptera, and flowering plant remains), all rather nicely preserved, without noticeable distortion. The amber piece was cut into two fragments for an optimal view of all inclusions. The fragment with the fungus gnat, also containing three myrmicine ants (Hymenoptera: Formicidae), three gall midges (Diptera: Cecidomyiidae), and stamen anthers and a leaf fragment of fabalean affinities (Hymenaea sp.), was assigned the collection number MAIG 6017 and is permanently deposited in the Museum of Amber Inclusions, University of Gdańsk, Poland. The presence of those syninclusions and their proximity to the fungus gnat prevented any further division of the amber that might have damaged them. For similar reasons, most sides of the piece could not be processed further, and only two surfaces were polished around the fungus gnat, allowing its visualization mostly in left profile and dorsal views. Photographs were taken using a Leica M205 C stereomicroscope equipped with a Leica DMC4500 digital camera. All images are digitally stacked photomicrographic composites of several individual focal planes, obtained using Helicon Focus 6.7 software packages. Figures were composed with Adobe Illustrator and Photoshop CC 2019 software. We follow the morphological terminology and the classification for Mycetophilidae presented in Søli (1997, 2017).

\subsection{Nomenclatural acts}

This published work and the nomenclatural act it contains have been registered in ZooBank (http://www.zoobank.org/, date of registry: 14 May 2021), with the following LSID (reference): urn:lsid:zoobank.org:pub:822C2AA5-6E01-4DDC8FEA-4F8BF225E9DF. The electronic edition of this work has been archived and is available from the following digital repositories: Deutsche Nationalbibliothek, US Library of Congress, Portico, and CLOCKSS.

\section{Systematic paleontology}

Order Diptera Linnaeus, 1758

Family Mycetophilidae Newman, 1834

Subfamily Mycetophilinae Newman, 1834

Tribe Exechiini Edwards, 1925

Genus Allodia Winnertz, 1863

Allodia Winnertz, 1863, p. 826.

\section{Type species}

Mycetophila ornaticollis Meigen, 1818; by subsequent designation by Johannsen, 1909, p. 104.

Allodia paleoafricana sp. nov.

LSID (species) urn:lsid:zoobank.org:act:D4BB63917842-4F9F-9420-F083136A255C

(Figs. 1-3) 


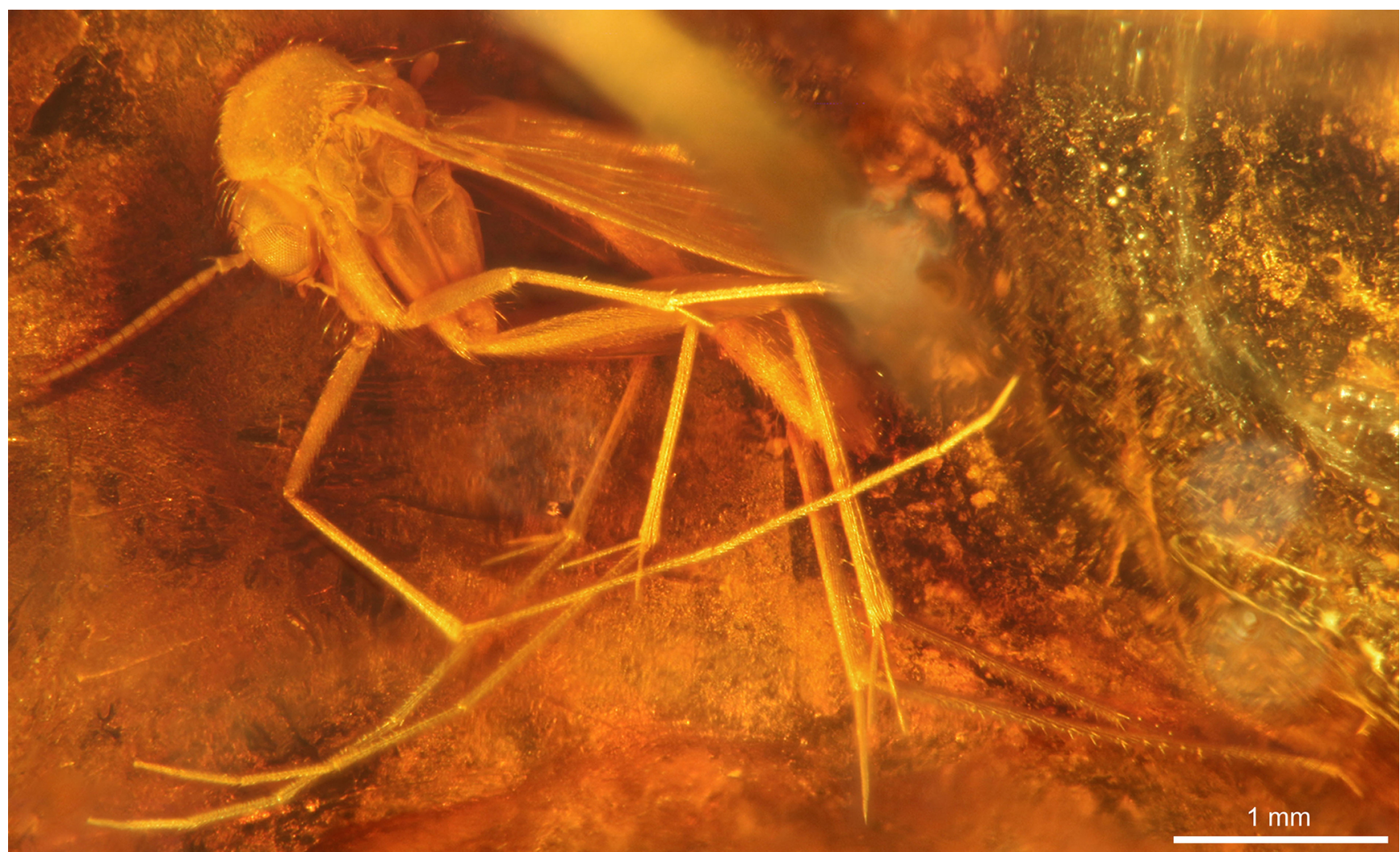

Figure 1. Allodia paleoafricana sp. nov., female, holotype MAIG 6017. Habitus in lateral view.

\section{Material}

Holotype MAIG 6017, a complete female specimen preserved in a piece of clear amber $(4.3 \times 3.2 \times 2.2 \mathrm{~cm})$ from a locality near Weldiya in the South Wollo Zone, Amhara Region, Ethiopia.

\section{Diagnosis (female)}

Scutum with strong anteromarginal setae, lateral prealar and postalar setae, and dorsocentral setae. Scutellum with two strong posterior setae. Antepronotum with three to four strong setae. Wing with stem of M-fork slightly shorter than $\mathrm{r}-\mathrm{m}$, base of M4-CuA fork nearly aligned with base of $\mathrm{r}-$ $\mathrm{m}, \mathrm{CuP}$ fading only shortly before M4-CuA fork. Metacoxa with one posterobasal and one posterodistal bristle.

\section{Description}

Head. Longer than broad, $0.54 \mathrm{~mm}$ long and $0.32 \mathrm{~mm}$ wide. Eyes widely separated, subcircular, about half as long as head, maximal diameter $0.27 \mathrm{~mm}$ (Fig. 2a). Three ocelli present, median ocellus larger than laterals, lateral ocelli touching eye margin. Antennae inserted near head's midlength, 1.25 times as long as thorax (Fig. 1); scape and pedicel subequal in size, $0.07 \mathrm{~mm}$ long, with gradual basal constriction, with few apical setae; flagellum progressively nar- rowed towards tip, $0.97 \mathrm{~mm}$ long, with 14 cylindrical articles clothed with fine trichia; first flagellomere longest, 1.6 times as long as scape, following flagellomeres all longer than wide, approximately as long as scape. Head covered with fine trichia, except for row of about five short setae near eye margin, above lateral ocellus (Fig. 2a).

Thorax. Antepronotum with three to four strong setae, other lateral sclerites bare (Fig. 2a). Mesonotum $0.90 \mathrm{~mm}$ long, $0.62 \mathrm{~mm}$ wide; scutum coated with thin, small, decumbent setae; additionally, with rows of long, erect setae: one anteromarginal, one to two laterals (prealar and postalar, more numerous around wing base), and two dorsocentrals (Fig. 2a-c); scutellum with two very long, posterior setae; several of these strong, dark thoracic setae detached from the specimen and floating around in amber matrix, although their points of insertion clearly visible, forming small, shallow pits on integument; setal apex apparently simply pointy.

Legs. All legs slender, pubescent; the tibiae covered by regular rows of trichia. Metacoxa with one anterodorsal bristle and one posterodorsal bristle (Fig. 2a). Profemur $0.90 \mathrm{~mm}$ long, $0.11 \mathrm{~mm}$ wide, thinner than others; metafemur $1.37 \mathrm{~mm}$ long, $0.20 \mathrm{~mm}$ wide; mesofemur $1.17 \mathrm{~mm}$ long, $0.12 \mathrm{~mm}$ wide. Protibia $1.09 \mathrm{~mm}$ long, $0.09 \mathrm{~mm}$ wide; mesotibia $1.15 \mathrm{~mm}$ long, $0.09 \mathrm{~mm}$ wide, with three to four anterodorsal bristles and one posterodorsal bristle; metatibia $1.56 \mathrm{~mm}$ long, $0.15 \mathrm{~mm}$ wide, with $13-14$ dorsal bristles; tib- 

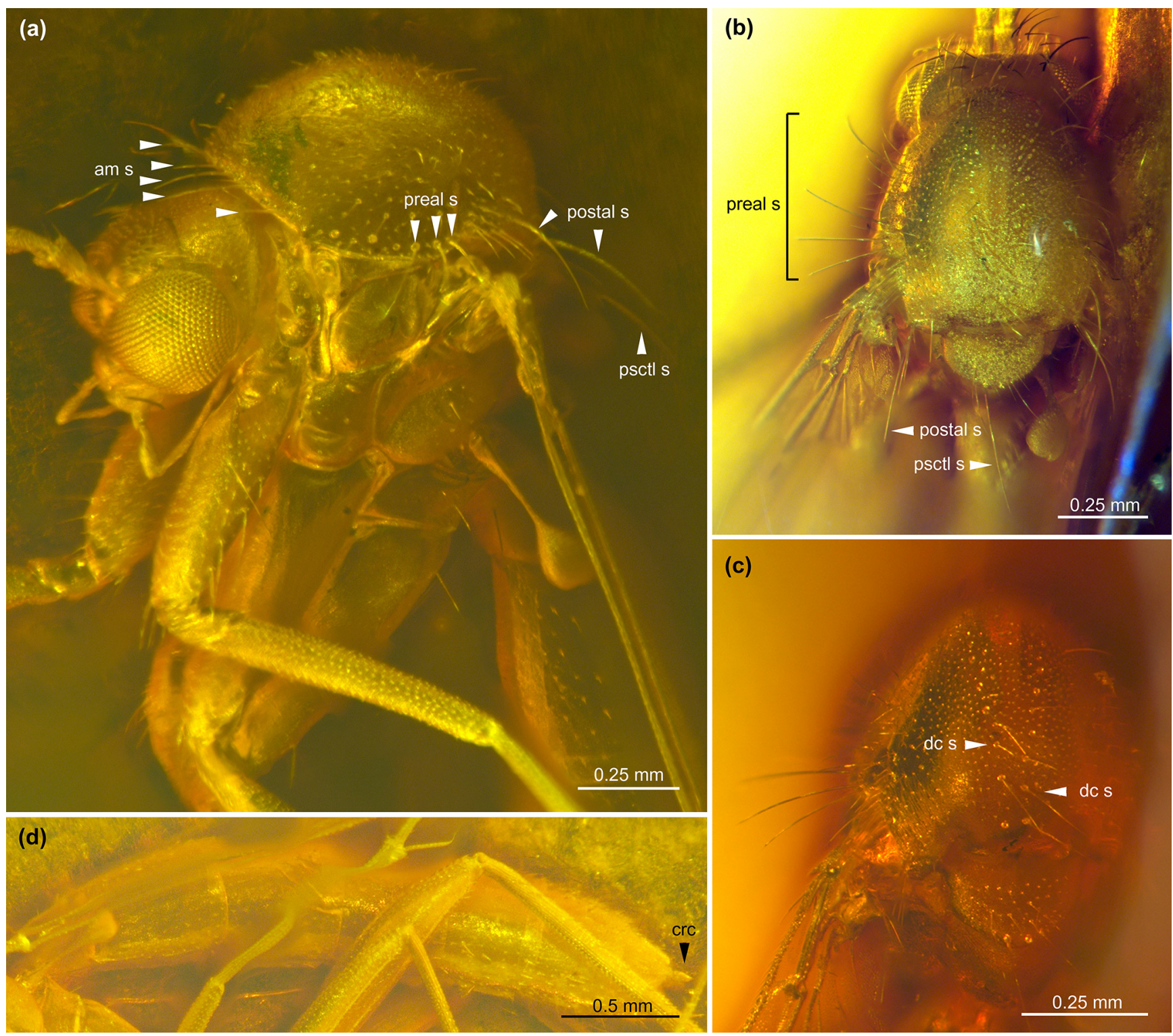

Figure 2. Allodia paleoafricana sp. nov., female, holotype MAIG 6017. (a) Details of head and thorax in lateral view, with indication of mesonotal setae. (b) Thorax in dorsal view, highlighting the lateral and posterior mesonotal setae. (c) Mesonotum in dorsal view, highlighting the rows of dorsocentral setae. (d) Abdomen in profile view. Abbreviations: am s, anteromarginal setae; crc, cerci; dc s, dorsocentral setae; postal s, postalar setae; psctl s, posterior scutellar setae; preal s, prealar setae.

ial spur formula $1-2-2$, longest metatibial spur about onethird of tibial length; tarsi slender, length of protarsomeres (in mm): TI 1.25, TII 0.75, TIII 0.52, TIV 0.30, TV 0.26.

Wings (Fig. 3). Wings $2.66 \mathrm{~mm}$ long, ca. $1.00 \mathrm{~mm}$ wide, with microtrichia arranged on membrane. Sc short, approximating but not ending in $\mathrm{R} ; \mathrm{R} 1$ reaching $\mathrm{C}$ on the apical wing quarter; $\mathrm{R} 2+3$ absent; $\mathrm{C}$ reaching apex of $\mathrm{R} 4+5$, both veins reaching margin before wing apex; $r-m$ slightly longer than stem of M-fork (M1-M2); M-fork situated distally of M4$\mathrm{CuA}$ fork. CuP short, fading before reaching wing margin, ending around level of M4-CuA fork. A1 weak, less distinct than other veins, thus ending unsure.

Abdomen. About as long as wings, narrowly joined to thorax, densely pubescent, with six distinct segments. Terminalia mostly invisible in profile view, partly concealed by left metatibia and pubescence; only a small, apically rounded part of cerci visible (Fig. 2d). 


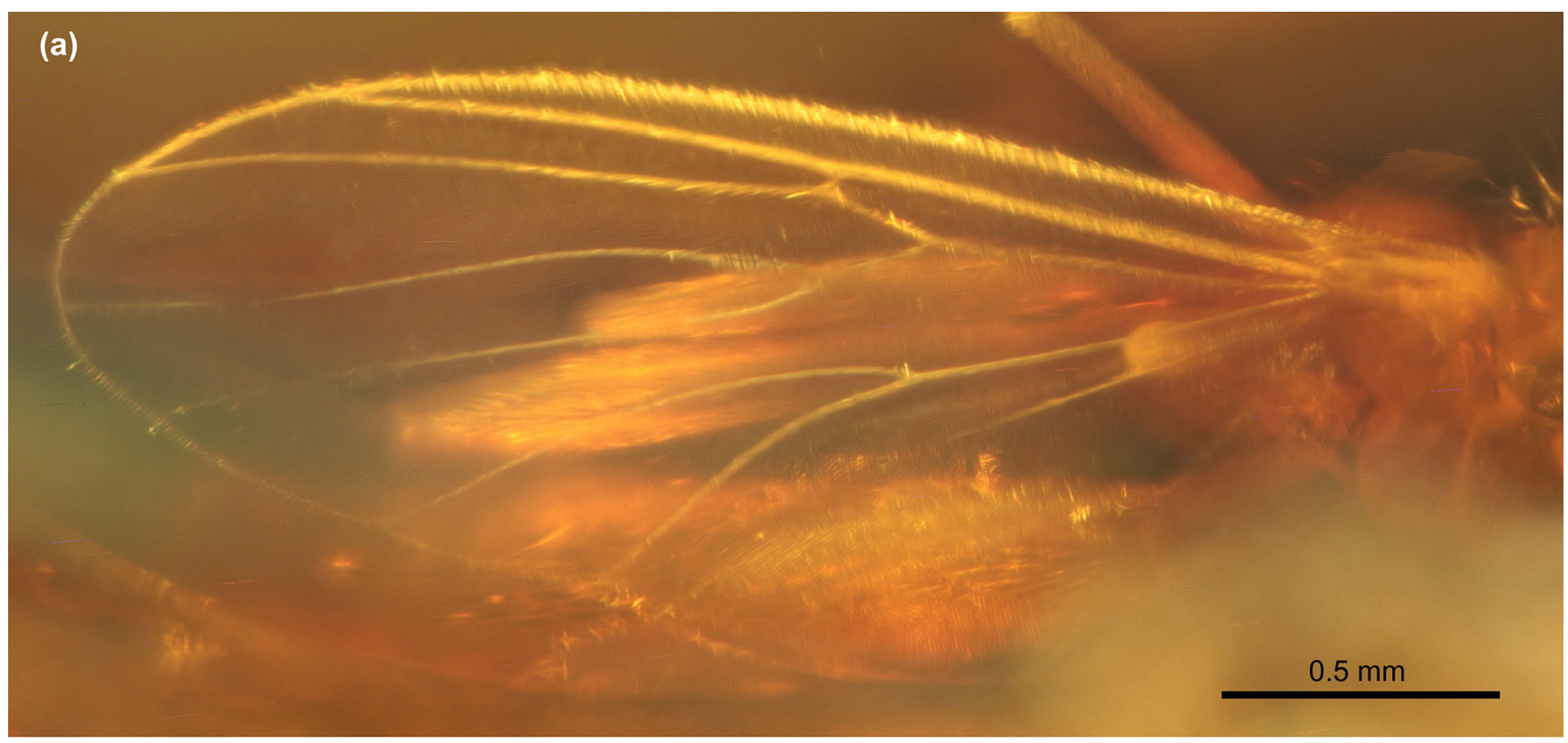

(b)

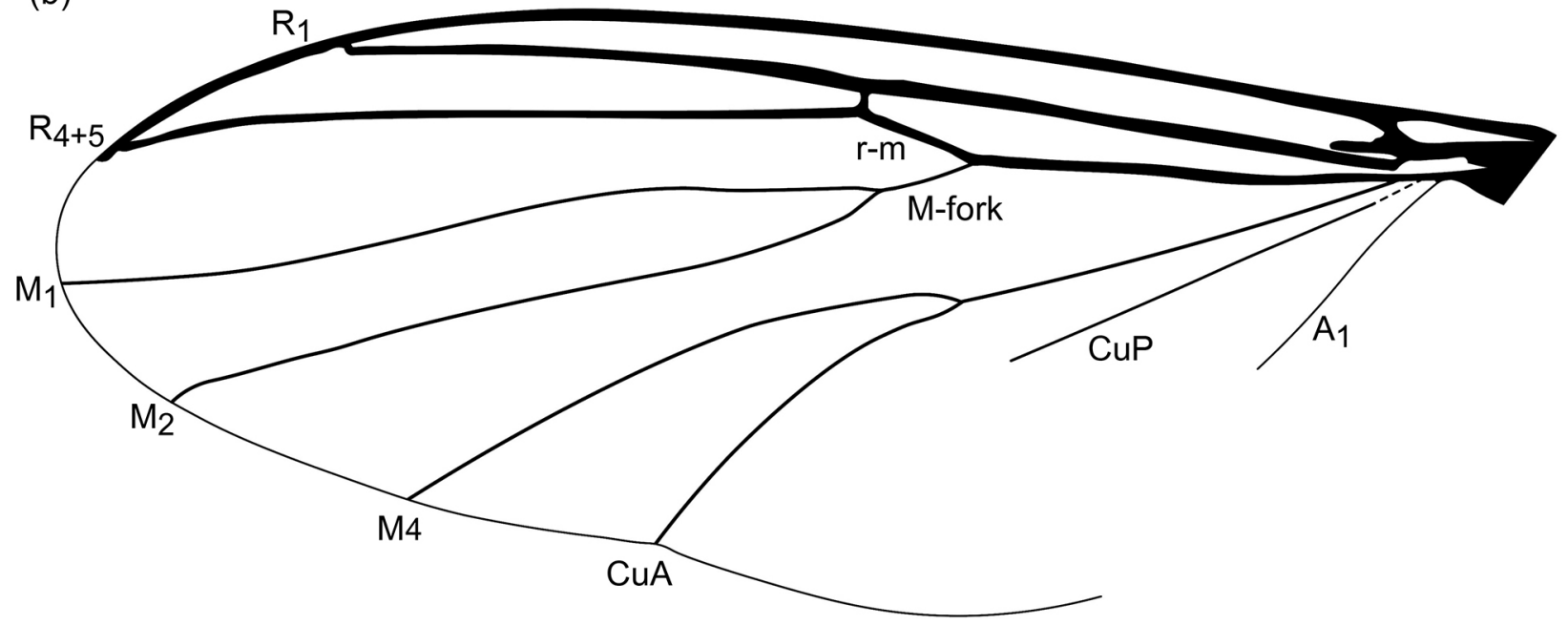

Figure 3. Wing of Allodia paleoafricana sp. nov., female, holotype MAIG 6017. (a) Photograph of left wing. (b) Drawing with indication of venation.

\section{Etymology}

The specific epithet combines palaiós (Greek, meaning "ancient") with Africa, in reference to the origin of the amber piece. The specific epithet is to be treated as an adjective in a genitive case.

\section{Discussion}

\subsection{Systematic placement}

Based on the key to Afrotropical Mycetophilidae proposed by Søli (2017), the placement of the new fossil within Mycetophilinae is supported by the lateral ocellus touching the eye margin and the absence of vein $\mathrm{R} 2+3$. The placement in Exechiini is supported by the anepisternum bare, although Tuomikoski (1966) and Rindal and Søli (2006) have warned about the unreliability of the character presence/absence of anepisternal setae after noticing its many variabilities in both tribes. The presence of a single strong bristle basally on the specimen's hind coxa may also indicate an Exechiini, yet, as weaker bristles have also been found in some Mycetophilini, this character is also insufficient to confidently assign the specimen (Tuomikoski, 1966). However, our studied specimen has a rounded lower part of the katepisternum covering the base of the mesocoxa (Fig. 2a), and no sagittal line is visible on its head, two characters considered reliable for placement in Exechiini (Tuomikoski, 1966). Within this tribe, the 
wing with the vein $\mathrm{CuP}$ not extending beyond the posterior fork (M4+CuA), which itself branches before the level of the point of furcation of the anterior fork $(\mathrm{M} 1+\mathrm{M} 2)$, excludes the genera Exechia; Pseudexechia Tuomikoski, 1966; and Rymosia Winnertz, 1863. Finally, the fossil specimen can be placed in the genus Allodia for its scutum with strong, erect setae arranged in rows (Søli, 2017). This would also warrant a placement in the subgenus Brachycampta Winnertz, 1863, according to Søli (2017). This placement would also be indicated by the base of the M4-CuA fork located before the base of $r-m$ (Fig. 3). However, the fossil has the wing with the stem of the anterior fork slightly shorter than $\mathrm{r}-\mathrm{m}$, a character of Allodia stricto sensu (str. s.) rather than Brachycampta according to Tuomikoski (1966) or Zaitzev (2003). Both subgenera are otherwise distinguished by abdominal color markings, a character unreliable on the Ethiopian fossil. Furthermore, according to Magnussen (2020), all these characters traditionally used to separate Allodia and Brachycampta have ambiguities. Instead, a further character seems more reliable: the bristles on the scutum and scutellum have an apical split in Allodia, while in Brachycampta, these bristles are simple (Magnussen, 2020, figs. 6B, C). These bristles are apparently simple on the fossil, suggesting Brachycampta, but preservation in amber prevents a clear view at higher magnification. Therefore, we prefer to leave the fossil unassigned to a subgenus until a definitive assessment of this tiny feature can be made.

\subsection{Exechiini and Allodia in the fossil record}

Representatives of Mycetophilidae are rather abundant in the fossil record, with numerous specimens described from Cretaceous or Cenozoic deposits (e.g., Matile, 1989, 1992; Blagoderov and Martínez-Delclòs, 2001; Blagoderov and Grimaldi, 2004; Oliveira and Amorim, 2014). Exechiini is estimated to date back to the Paleogene, with the oldest species described from the Eocene (ca. $53 \mathrm{Myr}$ old) French amber by Camier and Nel (2020) and diverse species fossilized in resins such as the $34-38 \mathrm{Myr}$ old Baltic amber (Burdíková et al., 2019). Based on the fossil record of the family and the abundant Cretaceous Mycetophilini, the crown Exechiini may be considered younger, with a hypothetical fast diversification during the Neogene (Rindal et al., 2007; Burdíková et al., 2019). However, to date, there is no clear time-calibrated phylogeny proposed for the family, challenging our comprehension of its diversification. $\mathrm{Al}$ lodia fossils have previously been described only from the Palearctic region, with seven species from the Eocene Baltic amber (Meunier, 1904, 1916, 1917, 1923), one species from the Oligocene of France, and two species from the Miocene of Croatia and Germany (Heer, 1849, 1856; Théobald, 1937). The Miocene Ethiopian species of Allodia enriches the preexisting data but also represents the first fossil species of the genus in Africa, thus bringing a new record of interest for further phylogenetic analyses such as a total-evidence dating approach.

\subsection{Comparison with extant Afrotropical Allodia}

Only seven African species have been described to date: one in the subgenus Brachycampta from the Comoros and six in the subgenus Allodia str. s. from Tanzania, Kenya, and South Africa (Matile, 1978; Magnussen et al., 2018). One undescribed species in the subgenus Allodia str. s. was also reported from Cameroon (Matile, 1978). The comparison with the Ethiopian fossil species, based on a female, is very limited: all these living species are based on males, using the terminalia and abdominal color markings as the main diagnostic characters. However, Allodia paleoafricana sp. nov. differs from all seven extant species at least by the presence of dorsocentral setae on the scutum (absent in the six species attributed to Allodia str. s.) combined with the wing with the stem of the M-fork slightly shorter than the $\mathrm{r}-\mathrm{m}$ (a character of Allodia str. s.).

\subsection{Paleoenvironment}

The palynomorphs from the amber-bearing bed suggest a humid, forested environment with freshwater for the depositional sites of the amber, such as a swamp or a marsh (Jim Cole, personal communication, 2015; Bouju and Perrichot, 2020). The presence of Allodia is concordant with this habitat since living members of the genus are typically found in moist forests (e.g., Søli et al., 2000; Kjærandsen et al., 2007; Magnussen, 2020). More generally, the greatest abundance of mycetophilids is found near moist places such as river banks or swamps (e.g., Matile, 1989; Oliveira and Amorim, 2014; Magnussen, 2020). Their presence in amber is also quite expectable as they are commonly observed in association with wood near the forest litter (Jakovlev et al., 2006; Magnussen, 2020), where tree resin typically flows. In fact, fungus gnats are commonly recorded in fossil resins (Matile, 1989, 1992; Blagoderov and Grimaldi, 2004).

\section{Conclusion}

The distribution and diversity of the genus Allodia, and to some extent of the tribe Exechiini, are rather well documented from the Holarctic, Palearctic, and Neotropical regions but remain largely understudied in the Afrotropical region. The discovery of Allodia in the Miocene Ethiopian amber constitutes the first fossil record of a Mycetophilidae in African amber. This provides valuable information on the distribution and evolutionary history of the genus as well as of Exechiini. The Ethiopian amber might be considered a significant new source of information regarding the ancient distribution of various taxonomic groups with an otherwise scant record from the Afrotropical region. These fossils 
could also provide important calibration points for investigation of much insect crown-group diversification.

Sample availability. The material included in this paper is permanently deposited in the Museum of Amber Inclusions at the University of Gdańsk, Poland, under the inventory number MAIG 6017.

Author contributions. VP and VB designed the study. JS and BB provided the fossil. $\mathrm{BB}$ and VP carried out the preparation of the amber sample. VB, SRG, MG, and VP prepared the photographs and illustrations and wrote the first draft of the paper. All authors contributed to the discussion and proofreading of the manuscript.

Competing interests. The contact author has declared that neither they nor their co-authors have any competing interests.

Disclaimer. Publisher's note: Copernicus Publications remains neutral with regard to jurisdictional claims in published maps and institutional affiliations.

Acknowledgements. We are grateful to Marcin Buzalski for access to the Ethiopian amber studied here and its repository at MAIG. We also thank Vladimir Blagoderov (National Museum of Scotland, Edinburgh, UK) for advice with the determination, and Corentin Jouault (University of Rennes) for comments on an earlier version of this paper. We thank the reviewers and the editor for insightful comments on the manuscript.

Financial support. Partial support for this work was provided by the Tellus-INTERRVIE program of CNRS INSU (project AMBRAFRICA to Vincent Perrichot, 2019), enabling Valentine Bouju and Vincent Perrichot's fieldwork in Ethiopia and work at the University of Gdańsk.

Review statement. This paper was edited by Carolin Haug and reviewed by Olavi Kurina and one anonymous referee.

\section{References}

Belay, T., Tesfay, I., Ayalew, A., Yohannes, G., Zewdie, T., Bekele, H., Tadesse, M., Demisse, T., and Alemu, T.: Geology of the Were-Ilu Area. Geological Survey of Ethiopia, Memoir 25, 56 pp., 2009.

Blagoderov, V. A. and Grimaldi, D. A.: Fossil Sciaroidea (Diptera) in Cretaceous ambers, exclusive of Cecidomyiidae, Sciaridae, and Keroplatidae, Am. Mus. Novit., 3433, 1-76, https://doi.org/10.1206/00030082(2004)433<0001:FSDICA>2.0.CO;2, 2004.

Blagoderov, V. V. and Martínez-Delclós, X.: Two new fungus gnats (Insecta, Diptera, Mycetophilidae) from the Lower Cretaceous of Spain, Geobios, 34, 63-67, https://doi.org/10.1016/S00166995(01)80045-0, 2001.

Bouju, V. and Perrichot, V.: A review of amber and copal occurrences in Africa and their paleontological significance, BSGFEarth Sci. Bull., 191, 17, https://doi.org/10.1051/bsgf/2020018, 2020.

Bouju, V., Feldberg, K., Kaasalainen, U., Schäfer-Verwimp, A., Hedenäs, L., Buck, W. R., Wang, B., Perrichot, V., and Schmidt, A. R.: Miocene Ethiopian amber: a new source of fossil cryptogams, J. Syst. Evol., https://doi.org/10.1111/jse.12796, online first, 2021.

Burdíková, N., Kjærandsen, J., Lindemann, J. P., Kaspřák, D., Tóthová, A., and Ševčík, J.: Molecular phylogeny of the Paleogene fungus gnat tribe Exechiini (Diptera: Mycetophilidae) revisited: Monophyly of genera established and rapid radiation confirmed, J. Zool. Syst. Evol. Res., 57, 806-821, https://doi.org/10.1111/jzs.12287, 2019.

Camier, M. and Nel, A.: The oldest fungus gnat of the tribe Exechiini in the lowermost Eocene Oise amber (Diptera: Mycetophilidae), Zootaxa, 4722, 91-98, https://doi.org/10.11646/zootaxa.4722.1.9, 2020.

Coty, D., Lebon, M., and Nel, A.: When phylogeny meets geology and chemistry: doubts on the dating of Ethiopian amber, Ann. Soc. Entomol. Fr., 52, 161-166, https://doi.org/10.1080/00379271.2016.1230477, 2016.

Coulié, E., Quidelleur, X., Gillot, P.-Y., Courtillot, V., Lefèvre, J.-C., and Chiesa, S.: Comparative K-Ar and Ar/Ar dating of Ethiopian and Yemenite Oligocene volcanism: implications for timing and duration of the Ethiopian traps, Earth Planet. Sc. Lett., 206, 477-492, https://doi.org/10.1016/S0012-821X(02)01089-0, 2003.

Edwards, F. W.: British fungus-gnats (Diptera, Mycetophilidae). With a revised generic classification of the family, Trans. Entomol. Soc. London, 1924, 505-670, 1925.

Hofmann, C., Courtillot, V., Féraud, G., Rochette, P., Yirgu, G., Ketefo, E., and Pik, R.: Timing of the Ethiopian flood basalt event and implications for plume birth and global change, Nature, 389, 838-841, https://doi.org/10.1038/39853, 1997.

Heer, O.: Die Insektenfauna der Tertiärgebilde von Oeningen und von Radoboj in Croatien. Zweiter Teil: Heuschrecken, Florfliegen, Aderflügler, Schmetterlinge und Fliegen, W. Engelmann, Leipzig, vi + 264 pp., 1849 (also in Neue Denkschr. Allg. Schweiz. Ges. Gesammten Naturwiss., 1, 1850).

Heer, O.: Über die fossilen Insekten von Aix in der Provence. Vierteljahresschr. Naturforsch. Ges. Zürich, 1, 1-40, available at: https://www.ngzh.ch/archiv/1856_1/1_1/1_2.pdf (last access: 12 October 2021), 1856

Jakovlev, J., Kjaerandsen, J., and Polevoi, A.: Seventy species of fungus gnats new to Finland (Diptera, Mycetophilidae), Sahlbergia, 11, 22-39, 2006.

Johannsen, O. A.: Diptera, Fam. Mycetophilidae, in: Genera Insectorum, Vol. 93, edited by: Wytsman, P., Brussels, Belgium, 141 pp., 1909.

Kieffer, B., Arndt, N., Lapierre, H., Bastien, F., Bosch, D., Pecher, A., Yirgu, G., Ayalew, D., Weis, D., Jerram, D. A., Keller, F., and Meugniot, C.: Flood and shield basalts from Ethiopia: magmas from the African superswell, J. Petrol., 45, 793-834, https://doi.org/10.1093/petrology/egg112, 2004. 
Kjærandsen, J., Kurina, O., and Ólafsson, E.: The fungus gnats of Iceland (Diptera, Keroplatidae \& Mycetophilidae), Insect Syst. Evol., 64, 61-96, 2007.

Kurina, O.: Description of four new species of Zygomyia Winnertz from Ethiopia and Uganda (Diptera: Mycetophilidae), Afr. Invert., 53, 205-220, https://doi.org/10.5733/afin.053.0113, 2012.

Linnaeus, C.: Systema naturæ per regna tria naturæ, secundum classes, ordines, genera, species, cum characteribus, differentiis, synonymis, locis, Tomus I, Editio decima, reformata, Salvius, Holmiæ, 824 pp., https://doi.org/10.5962/bhl.title.542, 1758.

Magnussen, T.: Integrative taxonomy and systematics of Allodia Winnertz (Diptera, Mycetophilidae), PhD thesis, University of Oslo Natural History Museum, Norway, 34 pp., 2020.

Magnussen, T., Kjærandsen, J., Johnsen, A., and Søli, G. E. E.: Six new species of Afrotropical Allodia (Diptera: Mycetophilidae): DNA barcodes indicate recent diversification with a single origin, Zootaxa, 4407, 301-320, https://doi.org/10.11646/zootaxa.4407.3.1, 2018.

Marshall, P.: New Zealand Diptera, No. 2, Mycetophilidae, Trans. New Zealand Inst., 28, 250-309, 1896.

Matile, L.: Diptères Mycetophylidae de l'archipel des Comores. Mém. Mus. Natl. Hist. Nat., Sér. A Zool., 109, 247-306, 1978.

Matile, L.: Family Mycetophilidae, in: Catalog of the Diptera of the Australasian and Oceanian Regions, edited by: Evenhuis, N. L., Bernice, P., Bishop Museum special publication no. 86, Bishop Museum Press, Honolulu, E. J. Brill, Leiden, 135-145, 1989.

Matile, L.: Review of the Afrotropical Gnoristinae (Diptera: Mycetophilidae), with descriptions of nine new species and first record of Synapha Meigen, Ann. Natal. Mus., 33, 189-202, 1992.

Meigen, J. W.: Systematische Beschreibung der bekannten europäischen zweiflügeligen Insekten. Erster Theil. F.W. Forstmann, Aachen, Germany, 332 pp., 1818.

Meunier, F.: Monographie des Cecidomyidae, Sciaridae, Mycetophylidae et Chironomidae de l'ambre de la Baltique, Ann. Soc. Sci. Bruxelles, 28, 93-275, 1904.

Meunier, F.: Beitrag zur Monographie der Mycetophiliden und Tipuliden des Bernsteins, Z. Dtsch. Geol. Ges., 68, 477-493, 1916.

Meunier, F.: Über einige Mycetophiliden und Tipuliden des Bernsteins nebst Beschreibung der Gattung Palaeotanypeza, N. Jb. Miner. Geol. Paläont., 1917, 73-106, 1917.

Meunier, F.: Nouvelle contribution à la monographie des "Mycetophilidae" (Ceroplatinae, Mycetophilinae et Sciophilinae) de l'ambre de la Baltique, Rev. Sci. Bourbonnais Cent. Fr., 1923, 14-34, 1923.

Newman, E.: Attempted division of British insects into natural orders, Entomol. Mag., 2, 379-431, 1834.

Oliveira, S. S. and Amorim, D. D. S.: Catalogue of Neotropical Diptera. Mycetophilidae. Neotrop., Diptera, 25, 1-87, 2014.
Perrichot, V., Boudinot, B. E., Cole, J., Delhaye-Prat, V., Esnault, J., Goldman, Y., Nohra, Y. A., and Schmidt, A. R.: African fossiliferous amber: a review, in: Abstracts of the 7th International Conference on Fossil Insects, Arthropods and Amber, edited by: Penney, D. and Ross, A. J., Siri Scientific Press, Manchester, p. 41, 2016.

Perrichot, V., Boudinot, B., Chény, C., Cole, J., Jeanneau, L., Schmidt, A. R., Szwedo, J., and Wang, B.: The age and paleobiota of Ethiopian amber revisited. 5th International Paleontological Congress, Paris, France, 9-13 July 2018, abstract book, p. 23, 2018.

Rindal, E. and Søli, G. E. E.: Phylogeny of the subfamily Mycetophilinae (Diptera: Mycetophilidae), Zootaxa, 1302, 43-59, https://doi.org/10.11646/zootaxa.1302.1.4, 2006.

Rindal, E., Søli, G. E. E., Kjærandsen, J., and Bachmann, L.: Molecular phylogeny of the fungus gnat tribe Exechiini (Mycetophilidae, Diptera), Zool. Scripta, 36, 327-335, https://doi.org/10.1111/j.1463-6409.2007.00285.x, 2007.

Schmidt, A. R., Perrichot, V., Svojtka, M., Anderson, K. B., Belet, K. H., Bussert, R., Dörfelt, H., Jancke, S., Mohr, B., Mohrmann, E., Nascimbene, P. C., Nel, A., Nel, P., Ragazzi, E., Roghi, G., Saupe, E. E., Schmidt, K., Schneider, H., Selden, P. A., and Vávra, N.: Cretaceous African life captured in amber, P. Natl. Acad. Sci. USA, 107, 7329-7334, https://doi.org/10.1073/pnas.1000948107, 2010.

Søli, G. E. E.: The adult morphology of Mycetophilidae (s. str.), with a tentative phylogeny of the family (Diptera, Sciaroidea), Entomol. Scand., 50, 5-55, 1997.

Søli, G. E. E.: Mycetophilidae (Fungus Gnats), in: Manual of Afrotropical Diptera, Vol. 2, Nematocerous Diptera and lower Brachycera, edited by: Kirk-Spriggs, A. and Sinclair, B. J., Suricata, 5, 533-555, 2017.

Søli, G. E. E., Vockeroth, J. R., and Matile, L.: Families of Sciaroidea, in: Contributions to a Manual of Palearctic Diptera, appendix, edited by: Papp, L. and Darvas, L., Science Herald, Budapest, Hungary, 49-93, 2000.

Théobald, N.: Les insectes fossiles des terrains oligocènes de France, Mém. Soc. Sci. Nancy, 2, 1-473, 1937.

Tuomikoski, R.: Generic taxonomy of the Exechiini (Dipt., Mycetophilidae), Ann. Ent. Fenn., 32, 159-194, 1966.

Winnertz, J.: Beitrag zu einer Monographie der Pilzmücken, Verh. K. K. Zool.-Bot. Ges. Wien, 13, 637-964, https://doi.org/10.5962/bhl.title.9961, 1863.

Zaitzev, A.: Fungus gnats (Diptera, Sciaroidea) of the fauna of Russia and adjacent regions. Part II, Dipterological Res., 14, 77-386, 2003. 